\title{
MANAJEMEN PENGELOLAAN OBAT DIINSTALASI FARMASI RUMAH SAKIT UMUM DAERAH dr. ZUBIR MAHMUD KABUPATEN ACEH TIMUR TAHUN 2021
}

\author{
Husna Hariani ${ }^{1}$, Arifah Devi Fitriani ${ }^{2}$, Mayang Sari ${ }^{3}$ \\ 1,2,3 Institut Kesehatan Helvetia Medan \\ Email: husnaapoteker2021@gmail.com
}

\begin{abstract}
Abstrak
Pengelolaan obat merupakan serangkaian kegiatan perencanaan, penganggaran, pengadaan, penyimpanan, pendistribusian, penghapusan, dan pengendalian guna mendukung upaya pencapaian tujuan organisasi. Penelitian ini bertujuan untuk mengetahui sistem pengelolaan obat pada layanan Instalasi farmasi RSUD dr.Zubir Mahmud Kabupaten Aceh Timur.

Penelitian ini merupakan penelitian kualitatif dengan jenis data yang digunakan adalah data primer dan data sekunder. Informan dalam penelitian ini terdiri dari kabid penunjang medis, kepala bagian perencanaan, ketua komite farmasi dan terapi,kepala instalasi farmasi, kepala gudang, koodinator farmasi rawat jalan, koordinator farmasi rawat inap, koordinator depo OK, staf pengadaan, staf keuangan dan pasien.

Hasil penelitian menunjukkan bahwa perencanaan obat dengan metode komsumsi dan belum menggunakan metode analisis VEN - ABC. Penganggaran persediaan obat menggunakan anggaran Badan Layanan Umum Daerah (BLUD). Pengadaan obat dilakukan dengan cara pembelian langsung tidak secara e-purcising karena menunggaknya tagihan obat, penyimpanan obat menggunakan sistem FIFO (First in first out) dan FEFO (First expired first out). Pendistribusian obat kepasien rawat jalan dengan cara individual prescribing sedangkan pasien rawat inap menggunakan cara one daily dispensing (ODD).

Kesimpulan dari penelitian ini adalah manajemen pengelolaan obat diRSUD dr.Zubir Mahmud Kabupaten Aceh timur sudah sesuai standar yang ditetapkan yaitu untuk perencanaan, pengadaan,penyimpanan dan distribusi obat sesuai dengan SOP yang ditetapkan oleh RSUD dr.Zubir Mahmud sedangkan untuk penganggaran mengacu pada Permendagri RI No.79 tahun 2008 akan tetapi ketersediaan obat masih kurang terpenuhi.Disarankan untuk memberikan pelatihanpelatihan untuk SDM yang ada dan penambahan sarana dan prasarana yang memadai diRSUD dr.Zubir Mahmud.
\end{abstract}

Kata Kunci : Manajemen, Ketersediaan Obat, Instalasi Farmasi

\begin{abstract}
Drug management is a series of planning, budgeting, procurement, storage, distribution, disposal, and control activities in order to support efforts to achieve organizational goals. This study aims to determine the drug management system in the pharmacy service of dr.Zubir Mahmud Hospital, East Aceh Regency.

This research is a qualitative research with the types of data used are primary data and secondary data. The informants in this study consisted of the head of medical support, the head of the planning section, the chairman of the pharmacy and therapy committee, the head of the pharmacy installation, the head of the warehouse, the outpatient pharmacy coordinator, the inpatient pharmacy coordinator, the OK depot coordinator, procurement staff, finance staff and patients.

The results showed that the drug planning using the consumption method and not using the VEN$A B C$ analysis method. Budgeting for drug supplies uses the Regional Public Service Agency (BLUD) budget. Drug procurement is carried out by direct purchase, not by e-purcising due to overdue drug bills, drug storage using the FIFO (First in first out) and FEFO (First expired first out) system. Distribution of drugs to outpatients by means of individual prescribing while inpatients uses the one daily dispensing $(O D D)$ method.

The conclusion of this study is that the management of drug management at Dr. Zubir Mahmud Hospital, East Aceh Regency is in accordance with the standards set, namely for planning,
\end{abstract}


procurement, storage and distribution of drugs according to the SOP set by RSUD dr. Zubir Mahmud, while for budgeting refers to Permendagri RI No. 79 year 2008 but the availability of drugs is still not met. It is recommended to provide training for existing human resources and the addition of adequate facilities and infrastructure at Dr. Zubir Mahmud Hospital.

Keywords: Management, Availability of Drugs, Pharmacy Installation

\section{Pendahuluan}

Rumah sakit merupakan salah satu dari sarana kesehatan tempat menyelenggarakan upaya kesehatan.Upaya kesehatan adalah setiap kegiatan untuk memelihara dan meningkatkan kesehatan, bertujuan menciptakan derajat kesehatan yang optimal bagi masyarakat (Siregar, 2004). Rumah sakit dituntut agar selalu meningkatkan kinerja dan kualitas pelayanan yang baik hingga dapat memenuhi standard dan kepuasan pasien.Untuk meningkatkan kualitas yang baik, semua aspek dan tenaga kerja di rumah sakit yang terkait dengan pelayanan kepada pasien harus memberikan yang terbaik termasuk pelayan farmasi (Adelheid, 2018).

Salah satu upaya dalam meningkatkan mutu pelayanan kesehatan rumah sakit dapat dilakukan dengan penggunaan obat-obatan yang rasional dan berorientasi kepada pelayananan pasien, penyediaan obat yang bermutu dan terjangkau bagi semua lapisan masyarakat (Siregar, 2004). Instalasi Farmasi Rumah Sakit (IFRS) adalah unit pelaksana fungsional yang menyelenggarakan seluruh kegiatan pelayanan kefarmasian di rumah sakit. Pelayanan kefarmasian di rumah sakit merupakan bagian yang tidak terpisahkan dari sistem pelayanan kesehatan Rumah Sakit yang berorientasi kepada pelayanan pasien, penyediaan sediaan farmasi, alat kesehatan, dan bahan medis habis pakai yang bermutu dan terjangkau bagi semua lapisan masyarakat termasuk pelayanan farmasi klinik. Semua sediaan farmasi, alat kesehatan, dan bahan medis habis pakai yang beredar di rumah sakit merupakan tanggung jawab instalasi farmasi, sehingga tidak ada pengelolaan sediaan farmasi, alat kesehatan, dan bahan medis habis pakai di rumah sakit yang dilaksanakan selain oleh Instalasi Farmasi(Kementerian KEsehatan, 2016).

Dari hasil penelitian tentang perencanaan dan pengadaan obat di Instalasi Farmasi RSUD dr.Zubir Mahmud Kabupaten Aceh Timur menunjukkan terjadinya kekosongan obat, keterlambatan pembayaran, distributor yang tidak menyanggupi penyediaan obat karena menunggaknya tagihan obat tahun 2020 yang belum selesai. Dan pada pertengahan tahun 2021 tim KFT (komite farmasi dan terapi) belum selesai merampungkan FORKID (formularium rumah sakit) tahun 2021, hal ini menyebabkan acuan pengadaan tetap mengadopsi FORKID yang lama, karena hal ini tidak ada perubahan atau penghematan anggaran yang dilakukan selama berjalan tahun 2021. Penggunaan analisis ABC terhadap nilai persediaan obat sangat berpengaruh terhadap anggaran belanja rumah sakit.

Dalam proses pemesanan obat di Instalasi Farmasi RSUD dr. Zubir Mahmud Aceh Timur dilakukan berdasarkan pengadaan langsung dengan perpesanan untuk selama 3 bulan pemakaian jadi dalam setahun ada empat rencana kebutuhan obat dari gudang pertriwulan (per 3 bulan).

Menurut wawancara dengan direktur Rumah Sakit Umum Daerah (RSUD) dr. Zubir Mahmud Aceh Timur, pendapatan rumah sakit saat ini sedang mengalami penurunan, sejak RSUD dr. Zubir Mahmud ditetapkan sebagai rumah sakit rujukan Covid-19. Selain karena ada pembatasan penerimaan pasien berobat dipoli tertentu, seperti Poli Bedah, Poli Jantung dan lainnya, juga banyak pasien yang enggan berobat di RSUD Zubir Mahmud, diduga karena takut terpapar Covid-19. Sejak 2020 penerimaan rumah sakit menurun dratis, karena pasien BPJS dan Pasien Umum (Non Covid-19) yang berobat turun drastis, di mulai bulan April 2020 sampai saat ini, sementara biaya operasional yang dikeluarkan justru meningkat. Sejak Covid-19 inilah pendapatan rumah sakit mengalami difisit anggaran. 
Pada proses perencanaan pengadaan obat sesuai dengan survey yang dilakukan dikerjakan oleh kepala gudang instalasi farmasi, perencanaan pengadaan obat dibuat tidak menggunakan analisis $\mathrm{ABC}$ akan tetapi masih menggunakan system manual yaitu sesuai dengan rata-rata penggunaan atau resep ditambahkan $20 \%$ dari jumlah total pengeluaran obat, hal ini lah yang menjadi salah satu faktor pemborosan anggaran, dikarenakan dari perencanaan obat tidak mempertimbangkan anggaran yang tersedia dirumah sakit.

Menurut hasil surview Rumah Sakit Umum Daerah (RSUD) dr. Zubir Mahmud Aceh Timur mengalami kelangkaan obat. Ada beberapa obat dengan penyakit-penyakit tertentu harus membeli obat di apotik luar rumah sakit. Hal tersebut dikarenkan kondisi rumah sakit sejak pandemi Covid-19 hingga saat ini di tahun 2021 sedang mengalami difisit anggaran.

Tabel 1. Persentase Pembelian Obat Diluar

\begin{tabular}{clcc} 
No & Ruangan & $\begin{array}{c}\text { Jumlah Item } \\
\text { Obat }\end{array}$ & Persentase Pembelian Obat Diluar \\
\hline 1 & Depo Rawat Jalan & 940 & $20 \%$ \\
\hline 2 & Depo Rawat Inap & 940 & $30 \%$ \\
\hline 3 & Depo Kronis & 940 & $10 \%$ \\
\hline 4 & Depo Ok & 940 & $15 \%$ \\
\hline
\end{tabular}

Sumber: Instalasi Farmasi RSUD dr.Zubir Mahmud

Dari tabel diatas dapat disimpulkan bahwa persentase obat kosong dimasingmasing depo beragam dikarenakan perbedaan kebutuhan obat dimasing-masing depo. Untuk depo rawat jalan jumlah obat kosong adalah 20\% dari 940 item obat, untuk depo rawat inap jumlah obat kosong adalah 30\% dari 940 item obat, untuk depo kronis jumlah obat kosong adalah $10 \%$ dari 940 item obat, dan untuk depo Ok jumlah obat kosong adalah $15 \%$ dari 940 item. Menurut hasil wawancara dengan Kepala Instalasi Farmasi, rata-rata obat yang kosong adalah obat Fast moving yaitu obat yang sering digunakan atau diresepkan.

Pada awal april tahun 2020 pandemi covid-19 memasuki Aceh, pemasukan rumah sakit turun drastis sehingga terjadi pengelolaan obat di instalasi farmasi menjadi tidak beraturan. Mulai dari pemesanan yang tertunda karena klaim dari BPJS menurun akibat pasien BPJS enggan berobat karena covid-19 dan keterlambatan obat yang datang karena terkendala tagihan obat pada distributor sehingga terjadi kekosongan obat yang dibutuhkan.

Kekosongan obat mulai terjadi dibulan april tahun 2021 dan secara bertahap, hal ini terjadi karena tidak ada pembayaran kepihak distributor obat mulai bulan juni 2020 . Karena hal tersebut banyak pasien mengeluh dan kecewa perihal ada obat yang dibutuhkan tapi kosong di rumah sakit, banyak juga pasien yang harus dialihkan ke rumah sakit lain karena obat yang dibutuhkan tidak tersedia sepenuhnya.

Berdasarkan permasalahan yang ditemukan dalam pengelolaan obat di Instalasi Farmasi Rumah Sakit, maka peneliti ingin meneliti sistem manajemen obat di Instalasi Farmasi RSUD dr. Zubir Mahmud Aceh Timur.

\section{Metode Penelitian}

Rancangan penelitian yang digunakan adalah penelitian kualitatif. Penelitian kualitatif adalah penelitian yang bermaksud untuk memahami fenomena tentang apa yang dialami oleh subjek penelitian misalnya perilaku, persepsi, motivasi, tindakan, dan lain-lain secara holistik dan dengan cara deskripsi dalam bentuk kata-kata dan bahasa pada suatu konteks khusus yang alamiah dan dengan memanfaatkan berbagai metode alamiah ( Shidiq $\&$ Choiri, 2021). Jenis pendekatan yang digunakan adalah pendekatan fenomenologi. 


\section{MIRACLE JOURNAL

Penelitian fenomenologi berorientasi untuk memahami, menggali, dan menafsirkan arti dan peristiwa-peristiwa, dan hubungan dengan orang-orang yang biasa dalam situasi tertentu. Ini biasa disebut dengan penelitian kualitatif dengan menggunakan pengamatan terhadap fenomena-fenomena atau gejala-gejala sosial yang alamiah yang berdasarkan kenyataan lapangan (empiris) (Shidiq \& Choiri, 2021). Pendekatan fenomenologi berusaha memahami makna dari suatu peristiwa atau fenomena yang saling berpengaruh dengan manusia dalam situasi.

Pada penelitian ini fenomena yang akan diteliti adalah tentang pengelolaan manajemen persediaan obat di Instalasi farmasi RSUD dr.Zubir Mahmud Kabupaten Aceh timur. Dimana dalam penelitian ini peneliti mencoba untuk menggali informasi dengan melakukan wawancara, observasi dan mengumpulkan data sekunder untuk mendukung informasi yang didapat dari hasil wawancara dalam upaya untuk memperoleh data tentang bagaimana manajemen pengelolaan obat yang dilakukan oleh pihak-pihak yang terkait di RSUD dr.Zubir Mahmud.

\section{Informan Penelitian}

Informan penelitian adalah orang yang dimanfaatkan untuk memberikan informasi tentang situasi dan kondisi latar belakang penelitian ( Shidiq \& Choiri, 2021).Informan merupakan orang yang benar-benar mengetahui permasalahan yang akan diteliti. Informan dalam penelitian ini ditetapkan dengan prinsip kecukupan dan kesesuaian. Kesesuaian berarti sampel dipilih berdasarkan pengetahuan yang dimiliki yang berkaitan dengan manajemen pengelolaan persediaan obat seperti pendidikan, jabatan, lama kerja dan pengalaman. Kecukupan berarti data yang diperoleh harus dapat menggambarkan seluruh kejadian yang berhubungan dengan manajemen pengelolaan persediaan obat. Informan terbagi tiga antara lain :

1. Informan utama : kepala instalasi Farmasi dan kepala gudang farmasi, Komite farmasi dan Terapi

2. Informan kunci : Kepala bagian perencanaan, kepala bidang penunjang,bagian keuangan, dan dokter.

3. Informan pendukung: Staf instalasi Farmasi dan staf gudang farmasi

Teknik Pengumpulan Data

Data yang digunakan dalam penelitian ini adalah terdiri dari dua jenis data yaitu sebagai berikut :

1. Data Primer yang diperoleh dari objek penelitian melalui:

a. Melakukan wawancara mendalam terhadap informan yang mengetahui permasalahan secara mendalam terkait dengan manajemen pengelolaan obat yang terdiri dari perencanaan, pengadaan, penganggaran, penyimpanan dan pendistribusian.

b. Melakukan pengamatan(Observasi)

Metode ini dilakukan dengan cara mengamati langsung kondisi di lapangan proses yang terkait dengan manajemen pengelolaan obat dan sarana prasarana di Instalasi farmasi RSUDdr.Zubir Mahmud.

2. Mengumpulkan data sekunder. Data sekunder diperoleh dari hasil pemeriksaan/telaah dokumen dan laporan-laporan yang terkait dengan obyek penelitian. Data sekunder yang dimaksud antara lain: profil RSUD dr.Zubir Mahmud, struktur organisasi instalasi farmasi, laporan anggaran belanja obat, laporan data stok obat, laporan obat kadaluarsa, laporan penggunaan obat generik, laporan persediaan obat akhir tahun (stok opname).

\section{Teknik Analisis Data}

Teknik analisis data yang digunakan dalam penelitian ini adalah adalah anlisis data 


\section{MIRACLE JOURNAL

kualitatif metode analisis tematik (thematic analysis). Metode ini sesuai dengan pendapat (Miles, dkk, 1992) yang menyebutkan analisis data kualitatif terdiri dari tiga komponen, yaitu:

\section{Reduksi Data}

Reduksi dapat diartikan sebagai proses pemilihan, pemusatan perhatian pada penyederhanaan, pengabstrakan, dan transformasi data yang muncul dari catatan-catatan lapangan. Reduksi data berlangsung secara terus menerus selama pengumpulan data berlangsung. Sebenarnya reduksi data sudah tampak saat penelitian memutuskan kerangka konseptual, wilayah penelitian, permasalahan penelitian, dan pendekatan penelitian, dan metode pengumpulan data yang dipilih. Pada saat pengumpulan data berlangsung, terjadilah tahapan reduksi selanjutnya membuat ringkasan, mengkode, menelusur tema, membuat gugus-gugus dan membuat catatan kaki. Pada intinya reduksi data terjadi sampai penulisan akhir penelitian.

\section{Penyajian Data}

Setelah mereduksi data, langkah selanjutnya yaitu menyajikan data. Dengan menyajikan data maka akan mudah memahami apa yang terjadi, merencanakan kerja selanjutnya berdasarkan apa yang telah dipahami tersebut.

Dalam penelitian kualitatif, penyajian data bisa dilakukan dalam bentuk kata-kata yang merupakan hasill penelitian. Jika terdapat data lain selain pernyataan pastisipan maka dapat ditambahkan gambar, dokumen, diagram, denah, model atau metafora. Bentuk penyajian data dalam kualitatif tidak terdapat batasan baku, sebagaimana karakteristik penelitian kualitatif yang fleksibel maka penyajian data kualitatif juga sangat dipengaruhi oleh kemampuan peneliti dalam merangkai kata-kata sehingga terbentuk kalimat yang mewakili hasil penelitian.

Untuk mempermudah melihat pola-pola jawaban informan, maka data dimasukan kedalam matriks jawaban. Semua jawaban dimatriks dianalisa dengan cara mencari persamaan dan perbedaan jawaban narasumber, mengelompokkan antara jawaban yang sama dan berbeda, mengutip ungkapan lisan dari informan yang menggambarkan tiap sudut pandang informan yang berbeda.

\section{Verifikasi}

Bagian terakhir dari analisis data adalah menarik kesimpulan dan verifikasi. berdasarkan data relevan yang dikumpulkan dan ditampilkan tersebut, kemudian ditarik satu kesimpulan untuk memperoleh hasil akhir penelitian.

\section{Pengecekan Validasi Temuan}

Menurut Suryono (2010), salah satu cara untuk uji validitas data dalam penelitian kualitatif yang cukup populer adalah teknik triangulasi. Triangulasi adalah teknik pemeriksaan keabsahan data yang memanfaatkan sesuatu yang lain diluar data itu untuk keperluan pengecekan atau sebagai pembanding terhadap data itu. Triangulasi pada hakikatnya merupakan pendekatan multimetode yang dilakukan peneliti pada saat melakukan penelitian, mengumpulkan, dan menganalisis data. Ide dasarnya adalah bahwa fenomena yang diteliti dapat dipahami dengan baik sehingga diperoleh kebenaran tingkat tinggi jika didekati dari berbagai sudut pandang. Memotret fenomena tunggal dari sudut pandang yang berbeda-beda akan memungkinkan diperoleh tingkat kebenaran yang handal. Pada dasarnya triangulasi ini merupakan teknik yang didasari pola pikir fenomenologi yang bersifat multiperspektif. Artinya, untuk menarik kesimpulan yang mantap, diperlukan tidak hanya dari satu sudut pandang saja. 


\section{Hasil Penelitian}

Wawancara mendalam dilakukan terhadap informan penelitian sebanyak 10 orang secara terpisah dengan menggunakan pedoman wawancara. Pemilihan informan berdasarkan kepada kewenangan dalam pelaksanaan pengelolaan obat dengan tugas pokok dan fungsi masing- masing, dianggap sebagai orang yang paling memahami/mengetahui dan terlibat langsung tentang manajemen pengelolaan obat mulai dari perencanaan, pengadaan, penganggaran, penyimpanan dan pendistribusian. Informan tersebut adalah Kabid Penunjamg Medik, Ketua KFT \& Sp.PD, Kasubag Perencanaan, Kasubid Pengadaan, Kepala Instalasi Farmasi, Kepala Gudang Farmasi, Koordinator Farmasi Rawat Jalan, Koordinator Farmasi Rawat Inap, Koordinator Farmasi Depo OK, dan Staf Keuangan.

Adapun karateristik informan dapat dilihat pada tabel berikut ini :

Tabel 2.Karateristik responden di RSUD dr. Zubir Mahmud tahun 2021

\begin{tabular}{clclcc}
\hline No & $\begin{array}{c}\text { Initial } \\
\text { Informan }\end{array}$ & $\begin{array}{c}\text { Umur } \\
\text { (tahun) }\end{array}$ & \multicolumn{1}{c}{ Jabatan } & Pendidikan & $\begin{array}{c}\text { Lama } \\
\text { Kerja } \\
\text { (tahun) }\end{array}$ \\
\hline 1 & YS & 43 & Kabid Penunjamg Medik & S2 & 21 \\
2 & TIR & 47 & Ketua KFT \& Sp.PD & S2 & 20 \\
3 & RF & 43 & Kasubag Perencanaan & S1 & 22 \\
4 & JS & 32 & Staf Pengadaan & D3 & 10 \\
5 & HR & 44 & Kepala Instalasi Farmasi & S1 Apt & 16 \\
6 & NH & 40 & Kepala Gudang Farmasi & SMF & 12 \\
7 & MR & 29 & Koordinator Farmasi Rawat Jalan & S1 Apt & 3 \\
8 & RA & 27 & Koordinator Farmasi Rawat Inap & S1 Apt & 3 \\
9 & MK & 30 & Koordinator Farmasi Depo & S1 Apt & 4 \\
10 & SH & 41 & Staf Keuangan & SMA & 21 \\
\hline
\end{tabular}

Sumber : Data Primer

\section{Analisis Manajemen PengelolaanObat \\ Perencanaan Obat}

Kegiatan perencanaan dan penentuan kebutuhan obat di gudang farmasi menggunakan metode konsumsi. Metode ini digunakan karena lebih mudah dalam penerapannya. Dalam proses perencanaan belum ada menggunakan suatu sistem atau metode VEN, analisis ABC, belum ada menghitung stok maksimum, stok minimum, dan lead time. Hal ini di dukung oleh pernyataan Informan sebagai berikut:

"Proses perencanaan kebutuhan persediaan obat yang dilakukan oleh instalasi farmasi RSUD dr. Zubir Mahmud melihat pemakaian obat sebelumnya atau metode konsumsi sesuai permintaan ruangan atau DPJP, di kumpulkan kemudian di rekap di tambah $10 \%$ dan sesuai dengan forkit, perencanaan obat belum ada menggunakan suatu sistem atau metode analisis VEN, analisis $A B C$, belum ada menghitung stok maksimum, stok minimum, dan tidak memperhitungkan lead time" (HR, 44 tahun)

Kegiatan perencanaan obat dilakukan dengan membuat perencanaan kebutuhan obat selama setahun dimana perencanaan dibuat dengan melihat data pemakaian obat sebelumnya ditambah buffer stok $10 \%$. Hal ini di dukung oleh pernyataan Informan sebagai berikut:

"Membuat perencanaan obat berdasarkan permintaan dari ruangan atau DPJP, per 3 bulan sekali dengan melihat pemakaian atau stok obat keluar pada 3 bulan sebelumnya ditambah buffer stok 10\%, kami belum menerapkan perencanaan berdasarkan jenis penyakit atau epidemiologi baru sebatas menggunakan metode komsumsi saja". (NH, 40 tahun)

Adapun tim yang terlibat dalam perencanaan obat menurut informan adalah kepala 
instalasi farmasi, kepala gudang dan komite farmasi dan terapi dan dokter dimana perannya ikut serta dalam penentuan jenis obat dan membuat formularium Rumah Sakit berikut pernyataan informan :

"Adapun tim yang terlibat dalam perencanaan obat adalah kepala instalasi farmasi, kepala gudang dan Komite Farmasi dan Terapi (KFT) dan dokter dimana peran KFT ikut dalam penentuan jenis obat dan membuat formularium Rumah Sakit”. (HR, 44 tahun)

Begitu pula pernyataan informan lain terkait keterlibatan tim KFT dalam perencanaan obat bahwa keterlibatan tim KFT dalam manajemen pengeloaan obat yaitu bertanggung jawab dalam penentuan jenis obat dan menyusun formularium rumah sakit, KFT meminta usulan dari user (dokter spesialis) berikut pernyataan informan:

"Tim KFT dalam managemen pengelolaan obat berperan dalam hal perencanaan obat yaitu bertanggung jawab dalam penentuan jenis obat yang akan di masukkan dalam formularium, KFT meminta usulan dari user obat-obat apa yang sering digunakan, obatobat yang kurang efisien, obat-obat yang pemakaiannya terlalu banyak dan obat-obat yang tidak dipakai selama pengadaannya, kemudian di jadikan evaluasi untuk formularium di tahun berikutnya. (TIR, 47 tahun)

Hasil wawancara terkait dengan proses perencanaan obat, Instalasi Farmasi rumah sakit Umum Daerah dr. Zubir Mahmud menggunakan metode konsumsi. Perencanaan obat tidak sesuai dengan kebutuhan pasien, baik dari segi jumlah maupun jenisnya.

\section{Penganggaran}

Pengganggaran adalah dana yang disediakan oleh pihak rumah sakit untuk menunjang kegiatan pengelolaan obat di gudang farmasi. Proses penganggaran untuk pengadaan obat di RSUD dr. Zubir Mahmud menjadi tanggung jawab bagian keuangan.

Berdasarkan hasil telaah dokumen berupa Laporan keuangan Obat menggunakan dana operasional dari Badan Layanan Umum Daerah (BLUD), Persentase dana yang tersedia sesuai dengan yang dianggarkan dalam Rencana Bisinis Anggaran (RBA). Persentase dana yang dikeluarkan untuk pengadaan obat dapat dilihat pada tabel berikut :

Tabel 3. Persentase dana yang tersedia untuk anggaran belanja obat di RSUD dr. Zubir Mahmud tahun 2019, tahun 2020 dan tahun 2021

\begin{tabular}{cccc}
\hline Tahun & $\begin{array}{c}\text { Total Anggaran Belanja } \\
\text { Rumah Sakit (Rp) }\end{array}$ & $\begin{array}{c}\text { Anggaran Belanja } \\
\text { Obat (Rp) }\end{array}$ & $\begin{array}{c}\text { Persentase (\%) } \\
\text { Anggaran Obat dari } \\
\text { TotalAnggaran Rs }\end{array}$ \\
\hline 2019 & 3.500 .000 .000 & 3.500 .000 .000 & $4,32 \%$ \\
2020 & 2.500 .000 .000 & 3.000 .000 .000 & $4,32 \%$ \\
2021 & 3.500 .000 .000 & 3.500 .000 .000 & $4,92 \%$ \\
\hline
\end{tabular}

Sumber: Kepala sub bagian Perencanaan RSUD dr.Zubir Mahmud

Tabel 3. di atas menunjukkan bahwa dana yang digunakan untuk belanja obat masih sangat rendah yaitu persentase dana yang tersedia untuk anggaran belanja obat ratarata pertahun hanya 4,32 \% bila dibandingkan dengan standar bahwa anggaran untuk belanja obat-obatan adalah sebesar 40-50\% dari total anggaran rumah sakit. Anggaran obat di rumah sakit masih sangat rendah karena rumah sakit lebih memprioritaskan kebutuhan lain untuk peningkatan sarana dan prasarana rumah sakit. Dana yang digunakan berdasarkan anggaran APBK dan dana BLUD. Hal ini juga didukung oleh hasil wawancara dengan informan sebagai berikut:

"Pada dasarnya penganggaran untuk obat dan BMHP serta alat medis habis pakai menggunakan anggaran APBK khususnya yang yang bersumber pada pendapatan dari jasa layanan atau dana BLUD. Penganggaran dilakukan dengan cara melihat anggaran tahun sebelumnya kemudian kita lihat tren dari pasien, berapa angka perbulan dan di rangkum menjadi angka setahun, di RBA kita melakukannya secara gelondongan karena 
setiap saat bisa berubah tergantung pasien dan tren obat. (RF, 43 Tahun)

Adapun tim yang terlibat dalam penyusunan anggaran adalah direktur rumah sakit ,kasubag perencanaan, Kasubag keuangan, bidang penunjang medis , Kabid pelayanan, hal tersebut sebagaimana pernyataan informan sebagai berikut :

"Penganggaran dilakukan di akhir tahun dengan melibatkan para kabid serta kabad TU untuk melihat kebutuhan dalam tahun yang akan berjalan". (RF, 43 Tahun)

\section{Pengadaan}

Pengadaan merupakan salah satu kegiatan merealisasikan perencanaan dan penentuan kebutuhan obat dirumah sakit. Dari hasil wawancara yang dilakukan oleh peneliti didapatkan bahwa proses pengadaan yang ada di RSUD dr. Zubir Mahmud Aceh Timur dimulai dari pengajuan dari gudang farmasi yaitu di gudang farmasi dilakukan pengecekan sisa stok barang yang menipis di catat dalam kartu stock kemudian direkap untuk dibuat perkiraan kebutuhan obat dengan melihat pemakaian obat sebelumnya dan sisa stok obat yang ada kedalam lembar RKO dan di serahkan ke kepala instalasi farmasi untuk disetujui, setalah RKO selesai barulah pihak gudang menyerahkan ke pihak tim pengadaan obat untuk menyeleksi jenis obat-obatan yang akan diadakan, di pilah obatobatan yang akan disediakan secara manual atau e-purchising lalu di cantumkan harga kemudian dilakukan pembelian.

"Proses pengadaan yaitu pihak pengadaan terlebih dahulu menunngu rencana pengadaan obat (RKO) yang dibuat oleh staf gudang farmasi, setelah RKO nya selesai, barulah pihak pengadaan obat menyeleksi jenis obat-obatan yang akan diadakan, pertama dipilah obat-obatan yang disediakan secara manual ataupun e-purchising kemudian dicantumkan harga. Untuk obat-obatan manual dibuatkan telaah staf yang di tanda tangani oleh direktur, baru di pilih penyedia obat-obatan tersebut, sementara metode ekatalog, langsung dilaksanakan pembeliaannya melalui aplikasi LPSE menggunakan ID pejabat pengadaan. (JS,32 Tahun)

Adapun tim yang terlibat dalam proses pengadaan obat menurut hasil wawancara adalah, pejabat pembuat komitmen,pejabat pengadaan, pejabat pekerja teknis kegiatan, tim pemeriksa barang dan bendahara pengeluaran. Frekuensi Pengadaan obat dilakukan tiga bulan sekali namun bila dalam keadaan tertentu bisa sesuai kebutuhan pelayanan. Pernyataan informan sebagai berikut :

"Tim yang terlibat untuk pengadaan obat adalah pejabat pembuat komitmen, pejabat pengadaan, pejabat pekerja teknis kegiatan, tim pemeriksa barang dan bendahara pengeluaran. Frekuensi pengadaan obat dilakukan tiga bulan sekali namun bila dalam keadaan tertentu bisa sesuai kebutuhan pelayanan "(JS,32 Tahun)

Untuk pemilihan pemasok obat RSUD dr. Zubir Mahmud tidak ada melakukan seleksi pemasok atau distributor obat. Distributor obat yang dipakai sudah dianggap sudah memenuhi persyaratan ketentuan yang berlaku yaitu ketentuan (8) bahwa pemasok harus memiliki TDR ( Tanda Daftar Rekanan), surat izin sebagai PBF (Pedagang Besar Farmasi) dari Depkes dan izin sebagai penyalur resmi dari pabrik obat. Pemilihan distributor hanya berdasarkan ketersediaan obat yang ada pada distributor tersebut bila satu distributor tidak mempunyai stok obat maka RSUD dr. Zubir Mahmud mencari distributor lain. Hal ini di dukung oleh pernyataan informan sebagai berikut :

"RSUD dr. Zubir Mahmud secara keseluuhan tidak ada melakukan seleksi distributor hanya berdasarkan ketersedian obat pada distributor tersebut, kalau distributor yang satu obat yang dibutuhkan tidak ada maka kami mencari distributor lain"(LA, 34 tahun)

Metode pembelian obat di RSUD dr. Zubir Mahmud adalah pengadaan dilakukan dengan sistem e-purchasing dan metode manual langsung ke distributor, namun pada masa pandemi sekarang metode yang di pilih adalah metode manual. Hal ini didukung oleh 
pernyataan informan sebagai berikut :

"Semenjak terjadinya pandemi, pendapatan rumah sakit menurun signifikan karena kunjungan pasien ke rumah sakit berkurang karena pembatasan kunjungan pasien,sehingga banyak distributor terjadi tunggakan piutang sehingga pemesanan secara manual dengan menyeleksi perusahaan mana saja yang mau dan bersedia memasukkan obat ke rumah sakit dr.zubir mahmud" (JS, 32 Tahun).

Tertundanya pembayaran obat sering terjadi dimana pembayaran obat tidak sesuai dengan waktu yang disepakati melewati tanggal jatuh tempo. Apalagi di masa pandemi covid-19 saat ini, dikarenakan anggaran yang ada sangat jauh berkurang dari tahun-tahun sebelumnya dan terjadi penuggakan pembayaran. Pembayaran obat di lakukan setelah obat yang dipesan atau yang di butuhkan oleh rumah sakit sudah kosong. Untuk proses pembayaran dilakukan setiap pencairan BPJS. Jumlah yang dibayarkan diambil dari dana operasional BPJS, setelah ditarik jasa layanan dan total pembayaran obat setiap pencairan BPJS disesuaikan dengan pencairan klaim perbulan, dimana proses pembayaran dilakukan setelah mendapat persetujuan dengan direktur baru dilakukan pembayaran oleh bagian keuangan. Hal ini didukung oleh pernyataan informan sebagai berikut:

"Pembayaran obat dilakukan ketika obat sudah jatuh tempo, terpending atau obatobat yang sangat di perlukan rumah sakit, pembayaran dilakukan setiap pencairan BPJS setelah ditarik jasa dan bersumber dari dana operasional klaim BPJS kemudian dibayarkan setelah mendapatkan persetujuan direktur."(SH, 41 Tahun)

Kendala lain dari bagian pengadaan selain penunggakan pembayaran karena pandemi covid-19 yang sangat berdampak tidak baik hingga terjadi kekosongan obat, hal lain yaitu kekosongan obat yang dibutuhkan di distributor sehingga rumah sakit harus meminjam obat ke rumah sakit terdekat dan rumah sakit yang ada hubungan kerja sama. Hal tersebut didukung oleh informan berikut ini :

"Bukan hanya karena pandemi, jika didistributor ada obat-obat yang kosong dan itu penting maka kita akan meminjam dari rumah sakit daerah terdekat atau rumah sakit lain yang punya hubungan kerja sama. (NH, 40 Tahun)

Berdasarkan hasil penelitian yang dilakukan oleh peneliti dengan menggunakan wawancara dan observasi, maka dapat disimpulkan bahwa proses pengadaan obat di gudang farmasi RSUD dr. Zubir Mahmud Aceh Timur belum sesuai standar karena masih sering terjadi kekosongan obat sehingga harus meminjam obat kerumah sakit yang sudah ada kerjasama dengan rumah sakit dr. Zubir Mahmud.

\section{Penyimpanan}

Penyimpanan merupakan kegiatan pengamanan terhadap obat-obatan yang diterima agar tidak hilang, terhindar dari kerusakan fisik maupun kimia, serta mutunya tetap terjamin. Berdasarkan hasil wawancara diketahui bahwa penyimpanan obat dilakukan berdasarkan bentuk sediaan seperti tablet, syrup, salep, atau jenis lainnya, alfabetis, kestabilan obat yaitu penyimpanan pada suhu tertentu, penyimpanan obat ini menggunakan sistem FIFO (First In First Out) yang artinya obat yang baru datang di letakkan di belakang sedangkan obat lama di letakkan di depan dan FEFO (First Expired First Out) artinya obatobat dekat tanggal kadaluarsa di letakkan di depan dan tanggal kadaluarsa yang lama di letakkan di belakang rak. Hal ini seperti yang diungkapkan oleh informan dibawah ini:

"Penyimpanan obat dilakukan dengan memisahkan, bentuk sediaan, alfabetis, kestabilan obat yaitu penyimpanan pada suhu kamar dan lemari pendingin dan secara FIFO (First In First Out) dan FEFO (First Expired First Out) untuk memudahkan pengambilan dan penyusunan serta untuk memudahkan melihat kadarluarsa obat. "(NH, 40 Tahun)

Obat-obatan yang akan kadaluwarsa akan di return ke distributornya masingmasing dan akan dilakukan pemusnahan jika obat sudah melewati batas return dan 
kadaluwarsa. Seperti halnya yang dikatakan informan berikut :

"Jika ada obat yang dekat tanggal kadaluwarsa kami return ke distributor tapi jika obat sudah melewati tanggal kadaluwarsanya tidak akan kami return hanya akan dilakukan pemusnahan" (NH, 41 Tahun).

Berdasarkan hasil wawancara dan observasi, maka dapat disimpulkan bahwa proses penyimpanan di gudang farmasi RSUD dr. Zubir Mahmud Aceh Timur dilakukan oleh petugas gudang farmasi sudah sesuai dengan standar yang berlaku. Namun ada beberapa kendala atau masalah yang ditemukan dalam proses penyimpanan antara lain yaitu gudang farmasi terlalu sempit dan kecil serta rak yang masih kurang sehingga penyusunan masih kurang rapi. Hal ini di dukung oleh informan berikut :

"Tentang kondisi gudang penyimpanan obat masih kurang, obat yang ada dalam kotak diletakkan di lorong-lorong gudang dan kurangnya valet untuk penyimpanan cairan dan rak-rak yang masih sedikit sehingga penyimpanan masih kurang efisien . " $(\mathrm{NH}, 40$ Tahun)

Tabel 4. Daftar Obat Kadarluarsa di Instalasi Farmasi RSUD dr. Zubir Mahmud tahun 2019, 2020 dan 2021

\begin{tabular}{clcc}
\hline No & \multicolumn{1}{c}{ Nama Obat } & $\begin{array}{c}\text { Jumlah } \\
(\mathbf{B O X})\end{array}$ & Total (Rp) \\
\hline 1 & Reco Tetes Telinga & 20 & 143.000 \\
2 & Ofloxacin Tetes Telinga (Tarivid) & 83 & 4.199 .800 \\
3 & Azythromicin 500 Mg & 41 & 1.457 .919 \\
4 & Doxycyline Cap & 5 & 323.140 \\
5 & Natrium Chlorida 3\% & 48 & 1.456 .032 \\
6 & Dimenhydrinat Tab & 3 & 48.651 \\
7 & Tramadol Injeksi & 55 & 1.320 .385 \\
8 & Bioralit 200 Ml Serbuk @ 25 & 5 & 123.750 \\
9 & Albendazole 400 Mg & 7 & 265.200 \\
10 & Cotrimoxsazole Tab & 3 & 57.400 \\
11 & Methil Ergometrin Inj @ 100 & 2 & 679.800 \\
12 & Forasma 2,5 Mg Tab @ 50 & 5 & 321.750 \\
\hline
\end{tabular}

Sumber : Instalasi farmasi RSUD dr.Zubir Mahmud tahun 2019

\begin{tabular}{clcc}
\hline No & \multicolumn{1}{c}{ Nama Obat } & $\begin{array}{c}\text { Jumlah } \\
\text { (BOX) }\end{array}$ & Total (Rp) \\
\hline 1 & KCL & 13 & 41,899 \\
2 & Magnesium Sulfhat 20\% & 22 & 73,194 \\
3 & Neostigmin INJ & 19 & 779,000 \\
4 & Serum Anti Tetanus 1500 & 250 & $32,524,750$ \\
5 & Noreepineprin Inj 4 Ml @ 5 Amp & 4 & 516,780 \\
6 & Herbesser Powder Inj 50 Mg & 1 & $1,543,699$ \\
7 & Atracurium Inj 2,5 Ml & 1 & 51,205 \\
8 & Spironolacton 100 & 26 & $5,096,520$ \\
9 & Zink Tablet & 4 & 241,596 \\
\hline Sumber $:$ Instalasi farmasi RSUD dr.Zubir Mahmud tahun 2020
\end{tabular}

No Nama Obat $\quad \begin{gathered}\text { Jumlah } \\ \text { (BOX) }\end{gathered} \quad$ Total (Rp)

\begin{tabular}{llll}
\hline 1 & Prednison TAB @ 100 & 212 & Rp. 2.803 .628 \\
\hline
\end{tabular}

Sumber : Instalasi farmasi RSUD dr.Zubir Mahmud tahun 2021

Di Instalasi Farmasi RSUD dr. Zubir Mahmud di temukan beberapa item obat kadarluarsa. Di tahun 2019 ditemukan 12 item obat, di tahun 2020 ditemukan 9 item obat dan di tahun 2021 ditemukan 1 item obat. Untuk tahun 2021 masih belum ada lagi penemuan karena belum di rekap akhir tahun. Hal ini diperkuat dengan informan berikut : 
"Untuk obat-obatan kadarluarsa di gudang farmasi masih tergolong tinggi disebabkan dari depo dan ruangan meminta disiapkan obat tersebut tapi peresepan kurang dan obatnya jadi jarang keluar sehinnga mengakibatkan obat-obat tersebut jadi kadarluarsa tapi untuk obat-obat lain yang mendekati tanggal atau bulan kadarluarsa yang bisa kita retur ya kita retur"'(NH, 40 Tahun).

\section{Pendistribusian}

Hasil wawancara, diketahui bahwa distribusi obat dilakukan RSUD dr. Zubir Mahmud adalah menggunakan sistem desentralisasi dari gudang farmasi ke farmasi rawat jalan, farmasi rawat inap, Depo OK, dan penyaluran bahan habis pakai ke ruangan rawat inap. Penyaluran obat dilakukuan apabila ada permintaan dari unit-unit untuk farmasi rawat jalan dan rawat inap dilakukan setiap hari melakukan permintaan obat ke gudang.

"Obat dan Bahan Medis Habis Pakai di salurkan atau didistribusi dari gudang sesuai permintaan dan amprahan dari ruangan-ruangan, depo rawat jalan, depo rawat inap dan depo OK. Kami kasih sesuai amprahan dan sesuai stok yang ada di gudang” (NH, 40 Tahun)

Dalam proses pendistribusian obat ke pasien berdasarkan hasil survei langsung di farmasi rawat jalan bahwa rata-rata waktu yang digunakan untuk melayani pasien mulai dari pasien menyerahkan resep sampai menerima obat dapat dilihat pada tabel berikut :

Tabel 5. Rata-rata waktu pelayanan resep obat jadi di instalasi farmasi RSUD dr. Zubir Mahmud

\begin{tabular}{ccc}
\hline No & Kegiatan & $\begin{array}{c}\text { Rata-rata waktu } \\
\text { (menit) }\end{array}$ \\
\hline 1. & Resep di terima petugas dan telaah resep & $5-10$ \\
2. & Menyiapkan obat sampai penyerahan obat & $10-15$ \\
& Total waktu pelayanan & $15-25$ \\
\hline
\end{tabular}

Sumber: Data Primer

Tabel 6. Rata-rata Waktu Pelayanan Resep Obat Racikan Di Instalasi Farmasi RSUD dr. Zubir Mahmud

\begin{tabular}{ccc}
\hline No & Kegiatan & $\begin{array}{c}\text { Rata-rata waktu } \\
\text { (menit) }\end{array}$ \\
\hline 1. & Resep di terima petugas dan telaah resep & $5-10$ \\
2. & Menyiapkan obat sampai penyerahan obat & $25-30$ \\
& Total waktu pelayanan & $30-40$ \\
\hline
\end{tabular}

Sumber: Data Primer

Tabel tersebut di atas dapat dilihat bahwa rincian kegiatan dengan rata-rata waktu pelayanan per lembar resep adalah untuk resep obat jadi adalah antara 15 - 25 menit dan resep racikan adalah antara 15 - 40 menit.Nilai ini berdasarkan standar yang ada yaitu untuk resep obat jadi 15 menit dan resep racikan 30 menit. Hal Ini didukung dengan pernyataan informan sebagai berikut:

"Untuk pelayanan resep obat jadi mulai dari resep di terima sampai obat di serahkan kepada pasien sekitar 15-20 menit namun untuk obat racikan normalnya lebih dari 15 menit tapi bisa sampai 30 menit."(MR, 29 Tahun)

Ketersediaan obat di RSUD dr. Zubir Mahmud masih banyak terjadi kekosongan obat dimana resep dokter tidak dapat terpenuhi dengan baik akibat pasien dan dokter sering mengeluh. Terutama di saat pandemi covid-19 seperti ini. Hal ini didukung dengan pernyataan informan sebagai berikut:

"Sejak pandemi covid-19 ini dampak buruknya yaitu kekosongan obat, pasien yang datang mengeluh karena ada obat yang di perlukan tetapi tidak tersedia di rumah sakit sehingga kami upayakan tidak langsung memberikan copy resep, kami hubungi dokter yang menulis resep untuk menanyakan obat pengganti jika stock nya masih 
ada,terkadang kami pinjam ke rumah sakit lain, jika dalam kasus pasien emergency dan jika pasien tidak mau menunggu baru kami kasih copy resep untuk di tebus diluar." (RA, 27 Tahun)

Hal lain dalam pendistribusian obat di ruangan bedah central dilakukan oleh apoteker yang bertanggung jawab yang langsung berkaitan dengan dokter spesialis, jika obat kosong maka dalam segera harus diinformasikan ke dokter-dokter yang bertanggung agar kegiatan operasi berjalan lancar. Seperti kata informan berikut :

"Sebelum melakukan operasi dokter akan mengisi form yang berisikan permintaan obat untuk tindakan operasi, jika obat kosong maka akan di beritahukan sebelumnya, dan jika seperti pandemi sekarang jika obat yang paling di butuhkan maka tindakan operasi ditunda atau ditiadakan, itu sangat merugikan pasien."(MK, 30 Tahun).

Karena pendistribusian obat yang masih kurang baik, pasien yang berobat mengeluh karena keterlambatan pemberian obat atau kekesongan obat padahal banyak sebagain pasien yang beralamatkan jauh dari rumah sakit, seperti wawancara dengan pasien di poli rawat jalan pada saat menunggu pemberian obat sebagai berikut:

"Sudah sering saya datang berobat ke sini, saya berobat butuh kesabaran lebih karena sering terjadi kekosongan obat, terkadang terpaksa saya beli obat diluar karena terlalu lama kosong". (AM, 32 tahun)

Ketersediaan obat di RSUD dr.Zubir Mahmud masih banyak terjadi kekosongan obat dimana resep dokter tidak dapat terpenuhi dengan baik akibat pasien dan dokter sering mengeluh. Hal ini didukung dengan pernyataan informan sebagai berikut:

"Pasien dan dokter juga seing mengeluh karena stok obat tidak ada di saat di perlukan, kami selalu menghubungi dokter untuk memberi informasi obat kosong, ya yang pasti dokter kecewa karena kasian pasiennyan jauh-jauh dan capek datang tapi obat tidak ada. Jika ada yang sama bisa kita ganti, jika tidak terpaksa pasien kita kasih copy resep untuk pasien umum, kalau pasien bpjs kadang kita suruh tunggu juga, kita cari solusi lain, jika pasien sudah tak mau terpaksa kami berikan copy resep saja untuk ditebus keluar." (RA,27 Tahun)

Hal ini diperkuat dengan hasil wawancara dengan beberapa dokter spesialis sebagai berikut :

"Banyak obat yang kosong, kadang obat-obat yang penting juga kosong. Kasian liat pasiennya yang memang perlu dan butuh. Kadang ketika instalasi farmasi menelpon saya kasih tau obat yang saya resepkan kosong, saya bilang beli diluar saja. (TIR,47 tahun)

Tabel 7. Persentase Peresepan Obat Generik Di Instalasi Farmasi RSUD dr.Zubir Mahmud tahun 2021

\begin{tabular}{ccccc}
\hline No & Bulan & Total R/ Obat & Total R/ Obat Generik & Persentase (\%) \\
& & & & \\
1 & Januari & 4219 & 3961 & $93,88 \%$ \\
2 & Februari & 4603 & 4418 & $95,98 \%$ \\
3 & Maret & 5499 & 5132 & $93,32 \%$ \\
4 & April & 4341 & 4055 & $93,41 \%$ \\
5 & Mei & 3389 & 3223 & $95,10 \%$ \\
6 & Juni & 3898 & 3647 & $93,56 \%$ \\
7 & Juli & 3817 & 3634 & $95,20 \%$ \\
8 & Agustus & 3775 & 3596 & $95,25 \%$ \\
9 & September & 3691 & 3514 & $95,20 \%$ \\
10 & Oktober & 4134 & 3936 & \\
11 & November & & & \\
\hline
\end{tabular}


Sumber : Data instalasi farmasi RSUD dr.Zubir Mahmud

Tabel 5 di atas menunjukkan bahwa penggunaan obat generik di RSUD dr.Zubir Mahmud sesuai dengan standar yaitu rata-rata $94,56 \%$ dari total peresepan obat dimana standar penggunaan obat generik adalah $82-94 \%$. Akan tetapi dari hasil wawancara dengan dokter spesialis menunjukkan sering terjadinya kekosongan obat generik, yaitu sebagai berikut :

"untuk penyediaan obat-obatan sering sekali mengalami kekosongan obat yang sering sekali obat-obat generik jadi banyak pasien datang kepada saya mengeluh obatobat yang rutin dipakai sering tidak tersedia jadi pasien langsung menebus obat diluar atau obatnya di copy resep". (TIR, 47 tahun)

\section{Pembahasan \\ Perencanaan}

Perencanaan dan penetapan kebutuhan merupakan langkah awal dalam proses pengelolaan obat. Dalam Arifah, (2014) perencanaan kebutuhan merupakan kegiatan untuk menentukan jumlah dan periode pengadaan obat sesuai dengan hasil kegiatan pemilihan untuk menjamin terpenuhinya kriteria tepat jenis, tepat waktu, tepat jumlah dan efisien. Perencanaan dilakukan untuk menghindari kekosongan obat dengan menggunakan metode yang dapat dipertanggung jawabkan dan dasar-dasar perencanaan yang telah ditentukan antara lain konsumsi, epidemiologi dan kombinasi metode konsumsi dan epidemiologi dan disesuaikan dengan anggaran yangtersedia.

Berdasarkan hasil penelitian di gudang farmasi RSUD dr. Zubir Mahmud Aceh Timur bahwa perencanaan dan penentuan obat di gudang farmasi RSUD dr. Zubir Mahmud Aceh Timur menggunakan metode konsumsi. Perencanaan kebutuhan obat di gudang farmasi dilakukan berdasarkan pada rata-rata jumlah konsumsi obat atau jumlah pemakaian pada periode sebelumnya dan ditambah $10 \%$ dari jumlah pemakaian sebelumnya. Metode ini digunakan sesuai dengan standar Rumah Sakit yaitu SOP dengan no.dokumen: MPO/SPO/001/RSUDZM. Pada tahap perencanaan obat-obatan yang akan dibuat dalam perencanaan adalah obat-obatan yang merujuk kepada formularium rumah sakit. Proses perencanaan obat di dr. Zubir Mahmud Aceh Timur yang selama ini dilakukan belum sesuai dengan prinsip dasar manajemen pengelolaan obat, sebab meskipun sudah dibentuk Komite Farmasi dan Terapi (KFT) dan formularium rumah sakit yang perencanaannya berdasarkan permintaan/usulan dari user (dokter) dengan menggunakan metode komsumsi namun belum ada menggunakan suatu sistem atau metode VEN, analisis $\mathrm{ABC}$, belum ada menghitung stok maksimum, stok minimum, dan lead time sehingga sering menyebabkan terjadinya kekosongan obat dan ketersediaan obat tidak dapat terpenuhi dengan baik.

Disamping itu juga instalasi farmasi tidak memperhitungkan waktu tunggu obat mulai dari di pesan sampai obat datang dari distributor, sangat perlu memperhitungkan waktu tunggu karena jarak antara distributor obat. Penyebab lain perencanaan obat berjalan belum optimal karena belum didukung oleh sumber daya manusia, dari hasil wawancara dengan kepala instalasi farmasi RSUD dr. Zubir Mahmud Aceh Timur bahwa masih kurangnya pengalaman kerja yang dimiliki sehingga perencanaan yang dilakukan belum optimal. Kurangnya pengetahuan tentang perencanaan obat dengan menggunakan metode analisis ABC-VEN, penentuan lead time hal ini karena belum pernah dilakukan pelatihan kepada para karyawan instalasi farmasi rumah sakit RSUD dr. Zubir Mahmud tentang perencanaan obat.

\section{Penganggaran}




\section{MIRACLE JOURNAL

Sumber dana merupakan salah satu input yang mendukung terlaksananya suatu proses. Proses akan berjalan sesuai dengan keinginan apabila didukung penuh dari segi pendanaannya. Begitu juga dengan pelayanan yang ada di RSUD dr. Zubir Mahmud Aceh Timur, pelayanan kesehatan akan berjalan dengan baik apabila didukung oleh pendanaan yang memadai.Penganggaran di RSUD dr.Zubir Mahmud (Negeri, 2018).

Hasil wawancara mendalam yang dilakukan oleh peneliti kepada informan diketahui bahwa anggaran yang dikeluarkan oleh RSUD dr. Zubir Mahmud Aceh Timur untuk pengadaan obat rata-rata sebesar \pm 13 miliar pertahun. Dana tersebut berasal dari BLUD. Persentase dana yang tersedia dibandingkan dengan kebutuhan rumah sakit sesuai dengan yang dianggarkan di dalam Rencana Bisnis Anggaran (RBA) pola pengelolaan keuangan Badan Layanan Umum Daerah (BLUD), untuk belanja kebutuhan obat yang ada mengikuti jumlah dana yang tersedia. Dana yang tersedia untuk anggaran belanja obat pada tahun 2019 rata-rata sebesar Rp. 13.295.971.932 dan tahun 2020 rata-rata sebesar Rp. 10.405.409.954 dan total anggaran operasional belanja rumah sakit pada tahun 2019 dan 2020 rata-rata sebesar Rp. 23.701.381.886 jadi persentase anggaran obat yang digunakan yaitu sebesar rata-rata 14,23\% dari total anggaran operasional rumah sakit. Hal ini masih sangat rendah bila dibandingkan dengan standar (13) bahwa anggaran untuk belanja obatobatan adalah sebesar $40-50 \%$ dari total anggaran operasioanal rumah sakit. Kendala yang dihadapi dalam penganggaran obat adalah kurangnya dana untuk pembelian obat. Dengan dana yang tersedia sekarang dirasa masih belum cukup untuk memenuhi permintaan kebutuhan yang meningkat hal ini menyebabkan ketersediaan obat tidak sesuaidenganperencanaan.Alokasidanauntukanggaranobatmasih rendah karena pihak

rumah sakit lebih mengutamakan peningkatan sarana dan prasarana rumah sakit untuk menunjang pelayanan rumah sakit.

Hal lainnya yang membuat anggaran berkurang adalah saat pandemic covid-19 yang terjadi di tahun 2020 hingga 2021 ini sangat bedampak buruk, karena pasien-pasien BPJS dan umum berkurang drastis berobat ke rumah sakit sehingga anggaran pun ikut berkurang. Jika anggaran terus berkurang akan berdampak tidak baik bagi rumah sakit, terutama dalam ketersediaan obat-obatan.

\section{Pengadaan}

Pengadaan merupakan suatu kegiatan untuk merealisasikan kebutuhan yang telah direncanakan dan disetujui melalui pembelian obat ke distributor. Pengadaan diRSUD dr.Zubir Mahmud sesuai dengan standar yang ditetapkan oleh Rumah sakit yaitu SOP dengan no.dokumen 03.01/06/IFRS/I/2017.

Tujuan pengadaan adalah untuk mendapatkan perbekalan farmasi dengan harga yang layak, dengan mutu yang baik, pengiriman barang terjamin dan tepat waktu, proses berjalan lancar dan tidak memerlukan tenaga serta waktu berlebihan di RSUD dr. Zubir Mahmud Aceh Timur tim yang terlibat di bagian pengadaan adalah pejabat pembuat komitmen,pejabat pengadaan, pejabat pekerja teknis kegiatan, tim pemeriksa barang dan bendahara pengeluaran.

Proses pengadaan obat di Rumah Sakit Umum Daerah dr. Zubir Mahmud menggunakan metode manual yaitu pembelian langsung, untuk menyesuaikan trend kebutuhan di Rumah Sakit. Hal ini sesuai Peraturan Presiden Republik Indonesia Nomor 95 Tahun 2007 disebutkan bahwa untuk mempercepat pengadaan dan pendistribusian bahan dan obat generik dipandang perlu segera menetapkan penyedia barang/jasa melalui penunjukan langsung( pembelian langsung).

Hal tersebut bila dianalisis lebih jauh bahwa pengadaan obat belum optimal karena perencanaan yang tidak baik sehingga mempengaruhi tingkat ketersediaan obat. Ketersediaan obat di Instalasi Farmasi akan berubah sesuai trend kebutuhan misalnya saja atas permintaan dokter untuk jenis tertentu yang tidak tercantum baik dalam formularium 


\section{MIRACLE JOURNAL

atau perubahan pola penyakit. Ketidaksesuaian obat yang tersedia dengan kebutuhan akan menyebabkan pelayanan tidak maksimal yaitu pasien tidak mendapatkan obat pada saat dibutuhkan sehingga tujuan pengobatan tidak tercapai.

Untuk mengatasi masalah ketidaktersediaan obat tersebut tidak jarang pihak rumah sakit melakukan pengadaan dengan meminjam obat yang dibutuhkan kerumah sakit lain yang telah terjalin kerjasama, hal ini dikarenakan permintaan yang tinggi dan mendesak, sedangkan persediaan yang dibutuhkan yang ada di dalam gudang mengalami. Pengadaanobat tidak sesuai dengan yang direncanakan, hal ini disebabkan karena kurangnya anggaran obat.

Berdasarkan hasil dan pembahasan diatas bahwa proses pengadaan sudah sesuai standar yang ada, namun ketersediaan obat belum terpenuhi sesuai dengan kebutuhan di rumah sakit hal ini karena dipengaruhi oleh perencanaan yang kurang baik, pembayaran obat yang tidak tepat waktu dan ketersediaan anggaran obat yang kurang serta masa pandemi covid-19

\section{Penyimpanan}

Penyimpanan adalah suatu kegiatan menyimpan dan memelihara dan menempatkan perbekalan farmasi yang diterima pada tempat yang dinilai aman dari pencurian serta gangguan fisik yang dapat merusak mutu obat. Penyimpanan di RSUD dr.Zubir Mahmud sesuai dengan standar yang ditetapkan oleh Rumah Sakit yaitu SOP dengan no.MPO/SPO/005/RSUDZM. Tujuan penyimpanan adalah untuk memelihara mutu sediaan farmasi, menghindari penggunaan yang tidak bertanggung jawab, menjaga ketersediaan, dan memudahkan pencarian dan pengawasan.

Berdasarkan hasil penelitian melalui survei diketahui bahwa pelaksanaan kegiatan penyimpanan obat di gudang farmasi RSUD dr. Zubir Mahmud Aceh Timur menggunakan sistem FIFO (First In First Out) dan FEFO (First Expired First Out). Artinya dalam penyusunan, obat- obatan yang baru datang diletakkan dibelakang dan obat-obatan yang lama diletakkan di bagian depan dan obat-obatan yang dekat tanggal kadaluarsa di letakkan di depan sedangkan obat-obatan yang tanggal kadaluarasa masih lama diletakkan di belakang. Hasil penelitian ini juga didukung oleh hasil penelitian Sheina, dkk, (2016) yang menyebutkan bahwa penyimpanan dan penyusunan obat di gudang Instalasi Farmasi RS PKU Muhammadiyah Yogyakarta Unit I menggunakan metode FIFO (First In First Out) dan FEFO (First Expired First Out) dan berdasarkan abjad, metode ini digunakan agar mempermudah petugas dalam pengambilan obat-obatan dan menjaga mutu obat obatan di Instalasi Farmasi RS PKU Muhammadiyah Yogyakarta Unit I. Menurut Sheina, dkk, (2016) pengaturan obat yang dilakukan di rak/lemari penyimpanan dapat memberikan kemudahan bagi petugas gudang dalam mencari barang saat dibutuhkan dan dapat membuat penyimpanan menjadi lebih efisien.

Dalam pedoman pengelolaan obat yang sudah diatur tentang bagaimana cara atau sistem penyimpanan obat-obatan yang baik dan benar. Tujuannya adalah untuk mempertahankan mutu obat dan menghindari kerugian akibat kesalahan penyimpanan obat. Penyimpanan obat sudah dilakukan dengan baik namun belum dapat memenuhi semua persyaratan yang ditetapkan karena keterbatasan SDM, sarana dan prasarana.

\section{Pendistribusian}

Proses pendistribusian obat di RSUD dr. Zubir Mahmud Aceh Timur dilakukan dengan sistem desentralisasi yaitu pendistribusian obat dari gudang farmasi ke farmasi rawat jalan, farmasi rawat inap, Depo OK dan ruang rawat inap untuk bahan habis pakai. Permintaan setiap unit akan obat semua ditujukan ke gudang farmasi. Pendistribusian obatobatan ke unit-unit rumah sakit di pusatkan di gudang tujuannya adalah untuk memudahkan pendataan dan pengontrolan terhadap obat-obatan yang dikeluarkan Jika stok obat di farmasi rawat jalan, farmasi rawat inap, Depo OK dan unit lainnya tersebut sudah habis 
atau sedikit jumlahnya, maka akan melakukan permintaan ke gudang farmasi yang disertai dengan bukti berupa surat permintaanobat atau amprahan. Pendistribusian obat ke pasien rawat jalan dengan cara individual prescribing sedangkan pasien rawat inap menggunakan cara One Daily Dispensing (ODD).

Pendistribusian obat ke pasien berdasarkan hasil survei langsung di farmasi rawat jalan rata rata waktu yang digunakan untuk melayani pasien mulai dari pasien menyerahkan resep sampai menerima obat rata- rata waktu pelayanan per lembar resep adalah untuk resep obat jadi adalah antara 15 - 25 menit dan resep racikan adalah antara 15 - 40 menit. Nilai ini cukup baik jika dibandingkan dengan standar rata-rata waktu yang digunakan untuk melayani resep sampai ke tangan pasien untuk Obat racikan maksimal 30 menit, non racikan 15 menit(9). Hal ini tidak sesuai dengan standar yang ditetapkan oleh Rumah Sakit yaitu SOP dengan no.dokumen MPO/SPO/034/RSUDZM.

Persentase peresepan obat dengan nama generik Pengukuran persentase peresepan obat dengan nama generik dimaksudkan untuk mengetahui kecenderungan dokter untuk meresepkan obat dengan nama generik yang berarti tertulis sebagai zat aktif sediaan sehingga ada kesepemahaman antara dokter dan farmasis dimana secara tidak langsung turut mencegah prescribing error, yang merupakan awal terjadinya medication error (10). Hasil penelitian yang dilakukan menunjukkan bahwa persentase penulisan resep dengan nama generik oleh dokter sudah sesuai dengan standar yaitu sebesar 94,56\% dengan standar penelitian yang dilakukan oleh (10) sebesar $82-94 \%$. Jadi penggunaan obat generik di RSUD dr.Zubir Mahmud sudah memenuhi standar yang ada . Akan tetapi dari hasil wawancara dengan pasien dan dokter masih banyak terjadinya kekosongan obat generik di RSUD dr.Zubir Mahmud.

\section{Kesimpulan}

Berdasarkan hasil penelitian terhadap manajemen obat di Instalasi Farmasi Rumah Sakit Umum Daerah dr. Zubir Mahmud Aceh Timur, yang berpengaruh terhadap rendahnya ketersediaan obat di rumah sakit umum daerah dr. Zubir Mahmud maka dapat disimpulkan sebagai berikut :

\section{PerencanaanObat}

Perencanaan kebutuhan obat di gudang farmasi RSUD dr. Zubir Mahmud Aceh Timur pada dasarnya sudah sesuai dengan prinsip dasar manajemen pengelolaan obat yaitu perencanaan menggunakan metode komsumsi dengan melihat kebutuhan pemakaian sebelumnya, namun belum maksimal karena perencanaan belum menggunakan suatu system atau analisis VEN, metode $\mathrm{ABC}$, belum menghitung stok maksimum dan minimum, dan belum menghitung lead time. Kurangnya pengetahuan tentang perencanaan obat karena belum pernah mengikuti pelatihan-pelatihan terkait dengan perencanaan obat.

\section{Penganggaran Obat}

Penganggaran persediaan obat yang ada di RSUD dr. Zubir Mahmud Aceh Timur menggunakan anggaran BLUD. Persentase dana yang tersedia untuk anggaran belanja obat adalah 14,23\% dari total anggaran operasional rumah sakit. Alokasi dana untuk anggaran belanja obat masih sangat kurang sehingga ketersedian obat dari perencanaan tidak terpenuhi.

\section{Pengadaan Obat}

Metode pembelian obat dilakukan dengan cara pembelian langsung dan $e$ purchasing, jangka waktu pembayaran tergantung pencairan klaim BPJS, frekuensi pembelian obat tiga bulan sekali tapi dalam keadaan tertentu pembelian obat bisa sekali dalam seminggu.

Pengadaan obat di gudang farmasi RSUD dr. Zubir Mahmud Aceh Timur belum 
berjalan dengan baik, sering terjadi kekosongan obat karena obat yang di pesan ke distributor tidak langsung dikirim karena pending yang disebabkan oleh tertundanya pembayaran obat tidak sesuai dengan waktu yang disepakati sering melewati tanggal jatuh tempo. dan terlambatnya distributor dalam mendistribusikan obat ke rumah sakit juga karena obat yang dipesan tidak ada atau kosong di distributor, Untuk mengatasi kekosongan obat maka dilakukan peminjaman obat kerumah sakit yang sudah ada kerjasama dengan rumah sakit dr. Zubir Mahmud Aceh Timur.

\section{Penyimpanan Obat}

Sistem penyimpanan obat yang dilaksanakan di RSUD dr.Zubir Mahmud menggunakan system sistem FIFO (First In First Out) dan FEFO (First Expired First Out). Penyimpanan di gudang farmasi RSUD dr. Zubir Mahmud Aceh Timur belum sesuai dengan standar dimana obat yang sudah kadaluarsa di simpan pada satu ruangan dengan obat yang belum kadaluarsa. Selain itu ada beberapa kendala atau masalah yang ditemukan dalam proses penyimpanan antara lain dan terjadinya penumpukkan kardus yang berisi obat-obatan hal ini disebabkan oleh kondisi gudang tempat penyimpanan obat terbatas.

5. Pendistribusian Obat

Waktu tunggu untuk pendistribusian obat ke pasien mulai dari pasien menyerahkan resep sampai pada penyerahan obat menggunakan waktu cukup lama untuk obat jadi yaitu 15- 25 menit dan obat racikan 15 - 40 menit hal ini disebabkan karena kurangnya tenaga farmasi khususnya di farmasi rawat jalan. Pendistribusian obat ke pasien rawat jalan dengan cara individual prescribing sedangkan pasien rawat inap menggunakan cara One Daily Dispensing (ODD).

\section{Daftar Pustaka}

Adelheid. (2018). Manajemen Pengelolaan Obat Terhadap Ketersediaan Obat Di Instalasi Farmasi Rumah Sakit Umum Daerah Kudungga Sangatta Kabupaten Kutai Timur Drug Management For Drug Supply In Pharmacy's Instalation General Hospital Kudungga Of Sangatta East Kutai.

Arifah, Ririn. (2014). Peraturan Menteri Kesehatan Republik Indonesia Nomor 58 Tahun 2014. 634.

Aryani L. (2020). Puskesmas Mertoyudan 1 Dan Puskesmas Mertoyudan 2 Kabupaten Magelang Periode 2020 Program Studi Diploma Iii Farmasi Puskesmas Mertoyudan 1 Dan Puskesmas Mertoyudan 2 Kabupaten Magelang Periode 2020.

Depkes RI. 6 Kmk No. 129 Ttg Standar Pelayanan Minimal Rs.Pdf. 129.

Direktorat Jenderal Binakefarmasian Dan Alat Kesehatan. Pedoman Pengelolaan Perbekalan Farmasi Di Rumah Sakit. Kementeri Kesehat Ri. 2010;1-80.

Keputusan Presiden Republik Indonesia Nomor 18 Tahun 2000 Tentang Pedoman Pelaksanaan Pengadaan Barang/Jasa Instansi Pemerintah. 1:105-12.

Kerja Ept. Direktorat Jenderal Bina Kefarmasian Dan Alat Kesehatan. Angew Chemie Int Ed 6(11), 951-952. 2010;13(April):15-38.

Miles Mb, Rohidi Tr, Mulyarto, Huberman Am. (1992). Analisis Data Kualitatif: Buku Sumber Tentang Metode Metode Baru / Matthew B. Miles, A. Michael Huberman. Tjetjep Rohendi; Pendamping M, Editor. Jakarta: Universitas Indonesia (Ui Press). 473-482 P.

Negeri Md, Indonesia R, Layanan B, Esa Ym. Permendagri Ri No.79. 2018;1(I).

Pemerintah Pn 60. Menteri Kesehatan Republik Indonesia Nomor: 129/Menkes/Sk/Ii/2008. Standar Pelayanan Minimal Rumah Sakit Menteri Kesehat Republik Indones. 


\section{MIRACLE JOURNAL

Peraturan Presiden Republik Indonesia Nomor 95 Tahun 2007 Tentang Perubahan Ketujuh Atas Keputusan Presiden Nomor 80 Tahun 2003. Pedoman Pelaks Pengadaan Barang/Jasa Pemerintah.

Permenkes Tahun 2016 Standar Pelayanan Kefarmasian Di Rumah Sakit. In Jakarta: Kementerian Kesehatan Ri. P. 63.

Sheina B, Umam Mr, Solikhah. (2016). Penyimpanan Obat Di Gudang Di Instalasi Farmasi Rs Pku Muhammadiyah Yogyakarta Unit I. J Kesehat Masy. 4(1):1-75.

Shidiq U, Choiri M. (2019). Metode Penelitian Kualitatif Di Bidang Pendidikan. Vol. 53, Journal Of Chemical Information And Modeling. 221 P.

Siregar, Doli D. (2004). Manajemen Aset: Strategi Penataan Konsep Pembangunan Berkelanjutan Secara Nasional Dalam Konteks Kepala Daerah Sebagai Ceo's Pada Era Globalisasi Dan Otonomi Daerah. Jakarta: Pt Gramedia Pustaka Utama.

Suryono. (2010). Kumpulan Instrumen Penelitian Kesehatan. Yogyakarta: Katalog Perpustakaan Politeknik Kesehatan Semarang. 138 P. Doli D. Siregar. Manajemen Aset: Strategi Penataan Konsep Pembangunan Berkelanjutan Secara Nasional Dalam Konteks Kepala Daerah Sebagai Ceo's Pada Era Globalisasi Dan Otonomi Daerah. Jakarta: Pt Gramedia Pustaka Utama; 2004. 